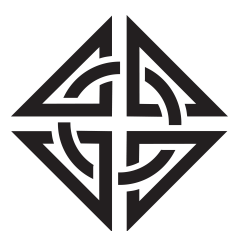

SCIENTIA

I RA N I C A
Sharif University of Technology

Scientia Iranica

Transactions C: Chemistry and Chemical Engineering

www.scientiairanica.com

\title{
Preparation, adhesion, and barrier properties of bituminous composite coatings on steel 37
}

\author{
H.R. Zamanizadeh ${ }^{\mathrm{a}}$, I. Danaee ${ }^{\mathrm{a}, *}$, M.R. Shishesaz ${ }^{\mathrm{a}}$ and D. Zarei ${ }^{\mathrm{b}}$ \\ a. Abadan Faculty of Petroleum Engineering, Petroleum University of Technology, Abadan, Iran. \\ b. Technical Faculty, South Tehran Branch, Islamic Azad University, Tehran, Iran. \\ Received 11 March 2015; received in revised form 12 February 2016; accepted 26 September 2016
}

\section{KEYWORDS}

Bitumen;

Nanocomposite

coating;

Clay;

Corrosion.

\begin{abstract}
A series of bitumen/nano clay nanocomposites has been prepared through solvent intercalation technique by mechanical agitation and sonication process. The structure of nanocomposite coatings was investigated by TEM, low angle X-ray diffraction, and Fourier-transform infrared spectroscopy. Polarization, salt fog test, and pull-off adhesion tests have been employed to investigate barrier properties of nanocomposite coatings. The results show that bitumen/MMT nanocomposite coatings are superior to the pristine bitumen coating in corrosion protection effects. Also, it was observed that the corrosion protection of bitumen/clay nanocomposite coatings improve as the clay loading is increased up to $4 \mathrm{wt} \%$
\end{abstract}

(C) 2016 Sharif University of Technology. All rights reserved.

\section{Introduction}

Bitumen is a natural polymer of low molecular weight, and it is viscoelastic like all polymers [1]. Bitumen is a mixture of aliphatic, aromatic, and naphthenic hydrocarbons. They are widely used to provide waterproofing and protective coating and as binders in road construction [2]. The barrier, adhesion, and inhibiting features have an important role in lifetime of coatings. The strength of coating/metal system is in proportion to contact time of system with the corrosive medium, changes in adhesion, barrier, and inhibiting properties. Aging and diffusion of corrosive agents such as $\mathrm{H}_{2} \mathrm{O}, \mathrm{O}_{2}$, and $\mathrm{H}^{+}$into coating/substrate interface can lead to blistering, reduction of stability the adhesion bond, increase of the speed of cathodic reaction, and degradation of coating and substrate [3].

In order to enhance the barrier properties of polymeric coatings, many researchers have used various kinds of additives such as extenders and inorganic

*. Corresponding author. Tel.: +98 61533226201

E-mail address: danaee@put.ac.ir (I. Danaee) pigments [4-7]. The nanocomposite approach has advantages over traditional fiber reinforced composites in the low filler loading range. In comparison to conventional pigments, addition of nanoparticles into polymeric coatings offers a more economical method and more durable protection against corrosion [8]. With the addition of small amount of nanofiller into different polymer matrix, the as-prepared nanocomposites exhibit substantial increase in various physical and chemical properties, including thermal stability, mechanical properties, flame retardant, barrier resistance, solvent resistance, and electro-rheology properties $[9,10]$.

Clay/polymer nanocomposites are a typical example of nanotechnology. Polymer-layered silicate nanocomposites have attracted increasing interest from both scientific and industrial perspectives, because this new class of materials shows dramatic improvements in mechanical properties, barrier properties, and thermal resistance at lower clay loading as compared with the pristine matrix (polymer without clay) [11-14]. This technology can now be applied commercially and has received great attention in recent years. The major 
development in this field has been carried out over the last one and half decades. The first commercial application of these materials was the use of clay/nylon-6 nanocomposites as timing belt covers for Toyota cars, in collaboration with Ube in 1991 [15].

The principle used in clay/polymer nanocomposites is to separate not only clay aggregates, but also individual silicate layers in a polymer. By doing so, the excellent mechanical properties of the individual clay layers can function effectively, while the number of reinforcing components also increases dramatically because each clay particle contains hundreds or thousands of layers. As a consequence, a wide range of en gineering properties can be significantly improved with a low level of filler loading, typically less than $5 \mathrm{wt} \%$. Their differences can be related to the polymer permeation between clay layers and dispersion uniformity of silicate sheets in polymer matrix. The high aspect ratio of silicate layers plays an important role in production of anti-corrosive coating systems $[16,17]$.

Montmorillonite (MMT) modified bitumen composites have been successfully used to improve both the physical and rheological properties of modified bitumen [18]. The goal of this study is to prepare the clay nanocomposite coatings in different clay contents. In addition, the effect of MMT on adhesion and anticorrosion properties of bituminous coating on steel 37 was investigated.

\section{Materials and methods}

\subsection{Preparation of nano-composites coatings}

Panels of steel 37 were used as metallic substrates. The panels were sandblasted to Sa2 $\frac{1}{2}$ (according to stocktickerASTM D609) and kept in desiccator. Prior to coating, the panels had been degreased with toluene and acetone. TW315 is a kind of bitumen emulsified in water which is complied with BS3416 type I standard as waterproof coating. Maximum volatile compounds of TW315 and maximum organic compounds are 60 and $1 \mathrm{wt} \%$, respectively, and its viscosity with Ford cup number 2 at $23^{\circ} \mathrm{C}$ is $30-60 \mathrm{~s}$. TW 315 was provided from Tiva Company. The natural montmorillonite clay (Cloisite $\mathrm{Na}^{+}$or $\mathrm{Na}^{+}-\mathrm{MMT}$ ) obtained from Southern Clay Products Co. Gonzales. TX.USA was used as additive. Some properties of this additive are shown in Table 1 .

Nanocomposite samples containing 2, 3, and 4

Table 1. Natural Montmorilonite nanoclay (Cloisite $\mathrm{Na}^{+}$) pigment properties.

\begin{tabular}{ccccc}
\hline $\begin{array}{c}\text { Particle } \\
\text { size }\end{array}$ & Color & Density & $\begin{array}{c}\text { Moisture } \\
\text { content }\end{array}$ & $\begin{array}{c}\text { X-ray } \\
\text { results } \\
\left(\boldsymbol{d}_{\mathbf{0 0 1}}\right)\end{array}$ \\
\hline$<25 \mu \mathrm{m}$ & Off-white & $2.86 \mathrm{~g} / \mathrm{cc}$ & $4-9 \%$ & $1.17 \mathrm{~nm}$ \\
\hline
\end{tabular}

wt\% of cloisite $\mathrm{Na}^{+}$were prepared through solvent intercalation technique. At the first stage, the stoichiometric amounts of cloisite $\mathrm{Na}^{+}$were added to $10 \mathrm{ml}$ of distilled water to make 2, 3, and $4 \%$ mixtures. Then, the mixtures were mechanically stirred by a propeller at $1000 \mathrm{rpm}$ for $120 \mathrm{~min}$ at room temperature followed by sonication process for $90 \mathrm{~min}$ at an ice bath. The ultrasonic lab device UP200H (200 W, $24 \mathrm{kHz}$ ) with amplitude and cycle gages at 100 and 1 , respectively, was used for sonication purpose. At the second stage, the stoichiometric amount of TW315 was added to clay/water mixtures to make 2, 3, and 4 wt $\%$ of clay/water/bitumen mixtures, followed by $45 \mathrm{~min}$ mechanical blending. Then, the mixtures were applied to the panels using 100 micrometer applicator. After evaporation of water, the dry film thickness of coatings measured by Elcometer 415 was $60 \pm 5 \mu \mathrm{m}$. The coatings were named PNC2, PNC3, and PNC4;PNC stands for polymer nanocomposite coating and the number in front of it specifies the weight percent of clay loading.

\subsection{Nano-composites coatings characterization}

To evaluate the intercalation/exfoliation of nanoclay in the bitumen matrix, X-Ray Diffraction (XRD) patterns were obtained from the surface of the molded nanocomposites. The XRD experiments were performed from $2 \theta=1-10^{\circ}$ with $\mathrm{X}^{\prime}$ Pert MPD instrument. The Co (Cobalt) radiation $(\lambda=1.78897 \AA$ ) was used as XRD source. A step size of $0.02^{\circ} / \mathrm{s}$, voltage of $40 \mathrm{kV}$, and current of $40 \mathrm{~mA}$ were used during the experiment.

In order to verify possible reactions between bitumen and Cloisite $\mathrm{Na}^{+}$and to identify the bonds of synthesized nanocomposites, the pristine bitumen and nanocomposite containing 4 wt\% Cloisite $\mathrm{Na}^{+}$ were characterized by Fourier-transform infrared spectroscopy (FTIR). Infrared spectra were conducted on a Brochure FTIR using ATR cell technique, with a wave number resolution of $4 \mathrm{~cm}^{-1}$ within the range of 600 $4000 \mathrm{~cm}^{-1}$.

To evaluate the intercalation/exfoliation of nanoclay in the bitumen matrix, TEM experiment was performed using Philips CM30. TEM allows for qualitative understanding of the internal structure and can directly provide information in real space, in a localized area, on morphology, and defect structures.

The electrochemical measurements were obtained using Autolab PGSTAT 302N. A conventional threeelectrode cell was used for electrochemical measurements. $\quad 3.5$ wt\% $\mathrm{NaCl}$ solution was employed as electrolyte. Coated panels were acted as working electrode with an exposed area of $2.009 \mathrm{~cm}^{2}$. A Pt electrode and a saturated $\mathrm{Ag} / \mathrm{AgCl}$ were employed as counter and as reference electrodes, respectively. The setup of the cell was placed in a Faraday cage. 
Polarization measurements were obtained in $3.5 \%$ $\mathrm{NaCl}$ after a 30-day immersion. The data was recorded from below $200 \mathrm{mV}$ to above $200 \mathrm{mV}$ of the open circuit potential $\left(E_{\text {ocp }}\right)$ at a scanning rate of $1 \mathrm{mV} \mathrm{s}^{-1}$. The polarization resistance $\left(R_{p}\right)$ was calculated from Tafel plots according to Stern-Geary equation [19]:

$$
R_{p}=\frac{\beta a \cdot \beta c}{2.303(\beta a+\beta c)} \times \frac{1}{I_{\mathrm{corr}}},
$$

where $\beta a, \beta c$, and $I_{\text {corr }}$ are anodic Tafel slope, cathodic Tafel slope, and corrosion current density, respectively. The corrosion rate was also calculated through the following equation:

$$
\mathrm{CR}=\frac{0.0032 I_{\mathrm{corr}} M W}{n d},
$$

where $I_{\text {corr }}, M W, n$, and $d$ are corrosion current density $\left(\mu \mathrm{A} \mathrm{cm}^{-2}\right)$, molar mass $\left(\mathrm{g} \mathrm{mol}^{-1}\right)$, charge number, and density $\left(\mathrm{g} \mathrm{cm}^{-3}\right)$ of tested metal, respectively.

ASTM B-117 is the widely accepted salt spray test to assess the corrosion protection of a protective coating [20]. Coated panels were cross scribed and placed at $45^{\circ}$ in a certified singleton salt fog chamber. ASTM B-117 test was carried out by CTS.114D salt spray fog chamber manufactured by B.AZMA Company. 5 wt\% $\mathrm{NaCl}$ solution $(\mathrm{pH}=7)$ sprayed at $38^{\circ} \mathrm{C}$ to this chamber. Scratched lines samples were made through one corner of the samples to the diagonally opposite corner of the sample, i.e. " $X$ " shaped. They were exposed for period of $500 \mathrm{~h}$.

The retaining of adhesion after immersion in 3.5 wt\% aqueous $\mathrm{NaCl}$ solution was measured using a direct pull-off adhesion test method according to ASTM D4541-02 [21] (self-aligning adhesion tester). For adhesion measurement, the samples were removed from the solution at the end of the 60-days immersion, rinsed completely with deionized water and allowed to dry for $48 \mathrm{~h}$ at ambient temperature. The dollies with an area of $0.5 \mathrm{~cm}^{2}$ were bonded to the coatings using an appropriate adhesive. A digital adhesion tester (Elcometer 108) with a maximum applied load of 18 MPa was employed. To ensure reproducibility and statistically characterize the test area, all the measurements were obtained from at least three experiments.

\section{Results and discussion}

\subsection{X-Ray Diffraction analysis (XRD)}

The state of intercalation or exfoliation of nanoclay structure in bitumen matrix was studied using low angle X-ray diffraction. Figure 1 shows the XRD pattern of 2,3 , and 4 wt\% clay-bitumen nanocomposites and cloisite $\mathrm{Na}^{+}$. As can be seen, pure cloisite $\mathrm{Na}^{+}$has one peak at $2 \theta=8.6095^{\circ}$, which is related to the $d$-spacing of $11.91694 \AA$ of clay layers according to

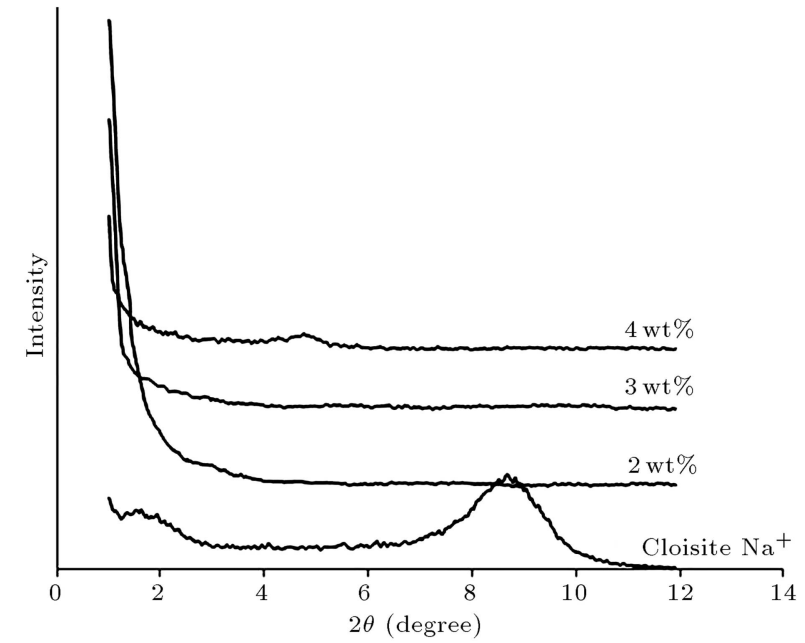

Figure 1. XRD patterns of pure Cloisite $\mathrm{Na}^{+}$and bitumen/clay nanocomposites.

Bragg's law (this value is in agreement with data sheet presented in Table 1 with a negligible difference). For nanocomposite specimens containing 2 and $3 \mathrm{wt} \%$ of nanoclay, there is no peak on their XRD patterns, which shows a great exfoliation of all nanoclay in bitumen matrix for these two nanocomposites. However, in case of 4 wt\% clay-bitumen nanocomposite, one peak with low intensity is appeared on its XRD pattern $(2 \theta=4.74195)$ that shifted to lower angle compared with that of pure cloisite $\mathrm{Na}^{+}$. This result shows that considerable intercalation $(d=21.62158 \AA)$ has occurred for some clay in $4 \mathrm{wt} \%$ clay-nanocomposite and other clays exfoliated in the bitumen matrix.

\subsection{Fourier transform infrared spectroscopy (FTIR)}

The FTIR spectra of bitumen and nanocomposite containing 4 wt\% clay are shown in Figure 2. The spectra of the bitumen show peaks at 2919 and 2851 $\mathrm{cm}^{-1}$ which are due to the asymmetric and symmetric $\mathrm{C}-\mathrm{H}$ stretching vibrations. The $\mathrm{C}-\mathrm{O}$ bond shows peak at $1030 \mathrm{~cm}^{-1}$. Also, peaks at 1457 and $1400 \mathrm{~cm}^{-1}$ are because of $\mathrm{C}=\mathrm{C}$ asymmetric stretching and $\mathrm{C}-\mathrm{H}$ bending in bitumen. In bitumen of both modified and base types, there are peaks at $677 \mathrm{~cm}^{-1}$ that return to $\mathrm{C}-\mathrm{H}$ bend. Also, there are other peaks in FTIR patterns of bitumen and modified bitumen that are the same, and there is no need for more identification. As can be seen, the presence of clay in the matrix does not affect the intensity of absorption of the characteristic FTIR peaks, and no new peaks are observed. It can be concluded that the clay is dispersed in polymer matrix, and there are no major chemical structural changes in bitumen, owing to the presence of clay [22].

\section{3. $T E M$}

To determine the intercalation or exfoliation of $\mathrm{Na}^{+}$MMT clay in the bitumen matrix, TEM observation 


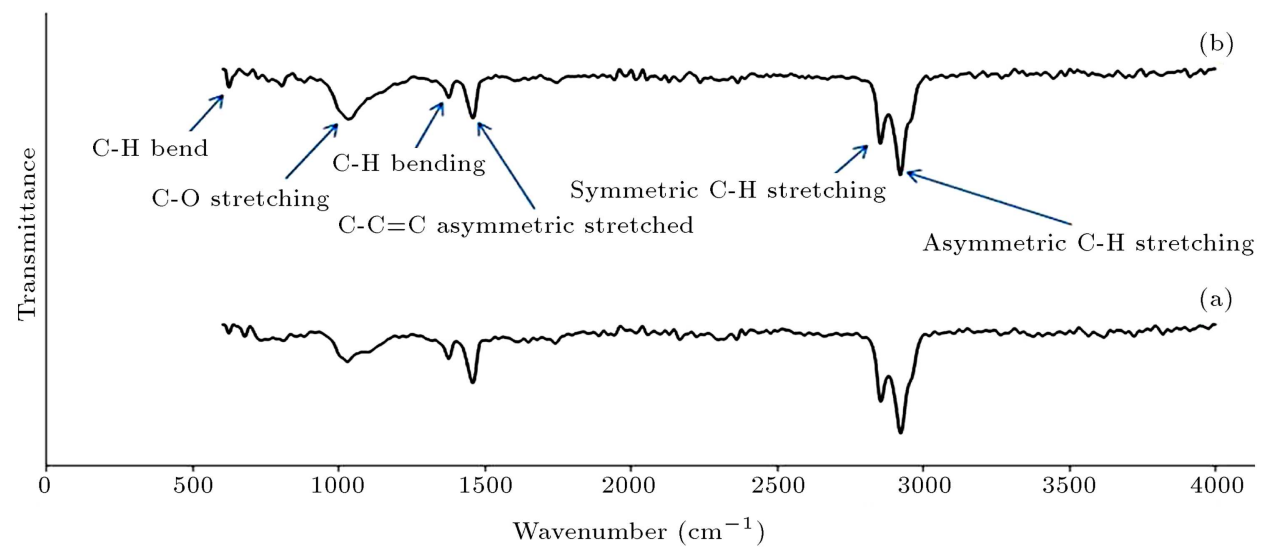

Figure 2. FTIR spectra of (a) pristine bitumen and (b) nanocomposites containing 4 wt\% organoclay.

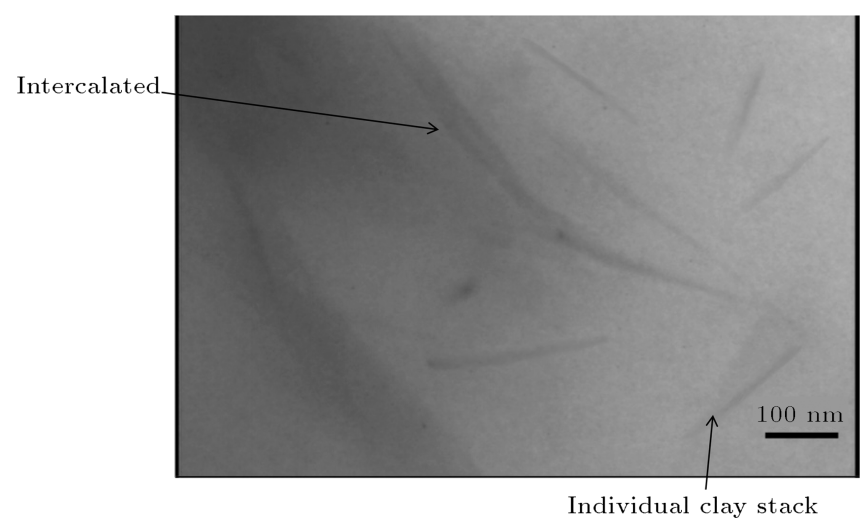

Figure 3. TEM image of $4 \mathrm{wt} \% \mathrm{Na}^{+}$-MMT

clay/bitumen.

was used. Figure 3 shows TEM of $4 \mathrm{wt} \% \mathrm{Na}^{+}$MMT clay/bitumen after the preparation procedure mentioned in Section 2.2. Dark lines and bright region in Figure 3 correspond to the clay layers and the bitumen matrix, respectively. The size of clay stacks is in the range of micrometer before sonication; however, the thickness of the clay layers reaches below $5 \mathrm{~nm}$ after that. It is concluded that the penetration of bitumen into the layers of $\mathrm{Na}^{+}-\mathrm{MMT}$ clay has successfully occurred. Individual layer stacks are found in the TEM image, and some larger intercalated clay can also be identified.

\subsection{Polarization measurement}

Figure 4 shows Tafel polarization curves of coating

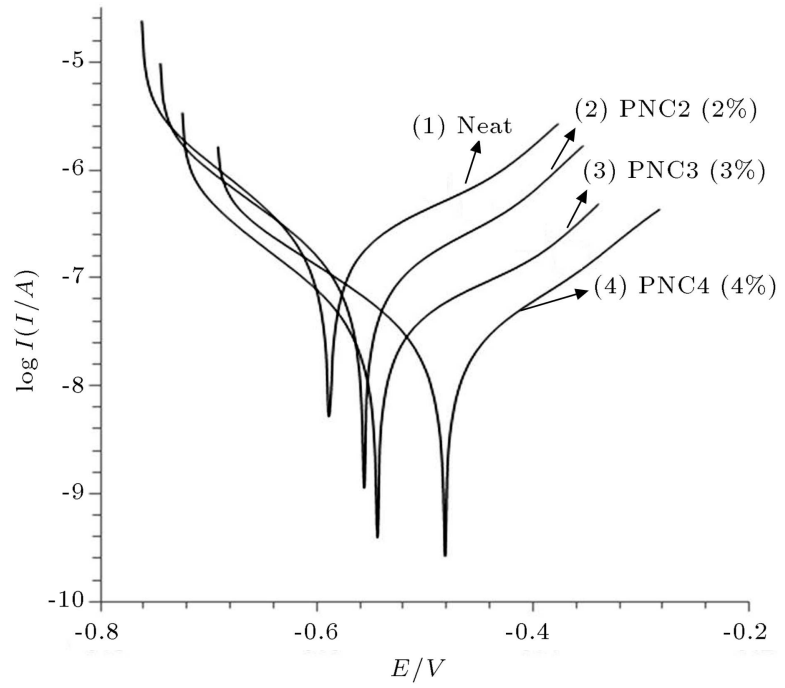

Figure 4. The polarization curves of neat bitumen and nanocomposite coatings after 30 days of immersion in 3.5 wt $\% \mathrm{NaCl}$ solution.

samples obtained after 30 days of immersion in $3.5 \%$ $\mathrm{NaCl}$ solution. Tafel calculations are listed in Table 2, where $E_{\text {corr }}, I_{\text {corr }}, \mathrm{CR}, \beta a, \beta c$, and $R_{p}$ are the corrosion potential, corrosion current density, corrosion rate, anode Tafel constant, cathode Tafel constant, and polarization resistance, respectively. The corrosion current density decreases and the corrosion potential increases as the amount of nanoclay increases. Clay/bitumen composite (PNC4) has the most positive value of $E_{c o r r}$, the highest value of $R_{p}$, and the lowest

Table 2. Potentiodynamic polarization parameters after 30 days of immersion of samples.

\begin{tabular}{|c|c|c|c|c|c|c|}
\hline & $\begin{array}{c}E_{\text {corr }} \\
(\mathrm{V})\end{array}$ & $\begin{array}{c}\boldsymbol{R}_{p} \\
\left(\mathrm{M} \Omega \mathrm{cm}^{-2}\right)\end{array}$ & $\begin{array}{c}\beta_{c} \\
\left(\mathrm{~V} \operatorname{dec}^{-1}\right)\end{array}$ & $\begin{array}{c}\beta_{a} \\
\left(\mathrm{~V} \operatorname{dec}^{-1}\right)\end{array}$ & $\begin{array}{c}I_{\text {corr. }} \\
\left(\mu \mathrm{Am}^{-2}\right)\end{array}$ & $\begin{array}{c}\text { Corrosion rate } \\
\left(\mathrm{mm} \text { year }^{-1}\right)\end{array}$ \\
\hline Neat bitumen & -0.588 & 0.1656 & 0.312 & 2.856 & 0.3675 & 0.004278 \\
\hline $2 \%(\mathrm{PNC} 2)$ & -0.556 & 0.3205 & 0.201 & 0.485 & 0.09426 & 0.001097 \\
\hline $3 \%(\mathrm{PNC} 3)$ & -0.544 & 0.8765 & 0.309 & 5.58 & 0.07217 & 0.0008402 \\
\hline $4 \%(\mathrm{PNC} 4)$ & -0.482 & 1.334 & 0.256 & 0.383 & 0.02485 & 0.0002893 \\
\hline
\end{tabular}


value of $I_{\text {corr }}$. The enhancement of corrosion protection effect is related to the increase in the tortuosity of the diffusion pathways of corroding agents due to the presence of the dispersed silicate nano-layer (nanoclay).

\subsection{Salt spray}

After exposure of samples for about $500 \mathrm{~h}$, the specimens were removed from the salt fog chamber to check for corrosion in the cut. In addition, formation of blisters and delamination was visually checked. Some differences are observed at the scratches and around them for all samples. As shown in Figure 5, after exposure of the samples for $500 \mathrm{~h}$, there are large blisters over the whole coated surface and around the scratches. In some regions, film delaminates and separates from base metal for pristine bitumen which is due to a more electrolyte penetration to this coating compared with other coatings. Also, in the scribed regions, brown adherent corrosion products are observed, which for the pristine bitumen is more and thicker than for other coatings. Therefore, more water penetration occurs in scribed regions for pristine bitumen with respect to other coatings. It can be seen from Figure 5 that the performance of the nanocomposites enhances in order of PNC2 < PNC3 < PNC4. For PNC4, a

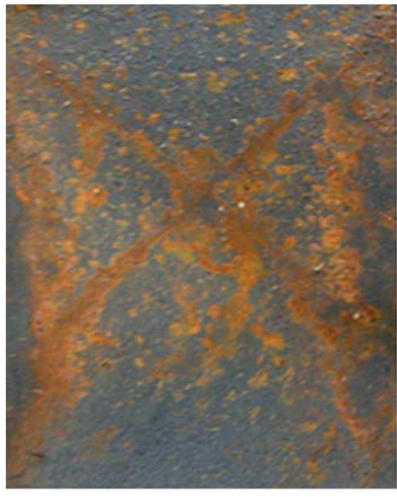

(a)

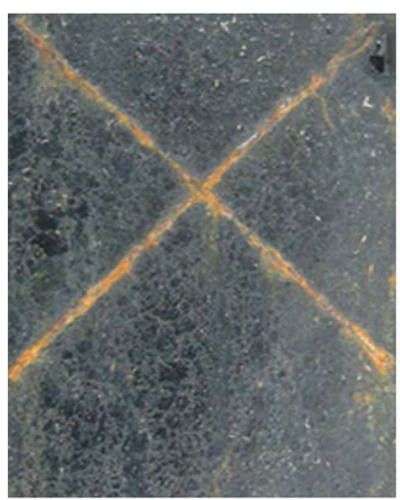

(c)

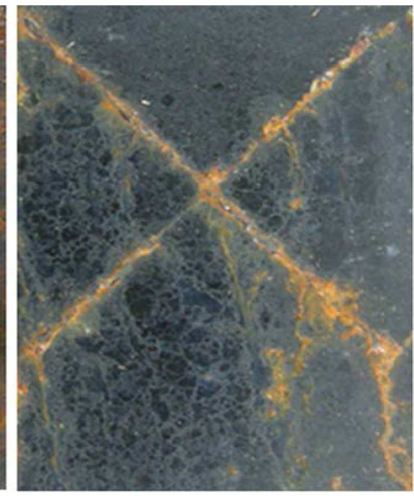

(b)

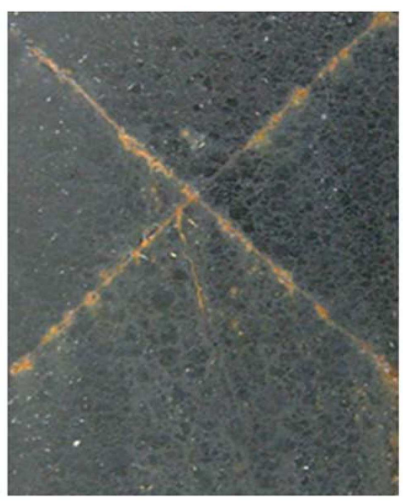

(d)
Figure 5. Samples after $500 \mathrm{~h}$ salt spray test: (a) Neat bitumen; (b) 2 wt\% clay/bitumen coating; (c) 3 wt\% clay/bitumen coating; and (d) 4 wt\% clay/bitumen coating.
Table 3. Pull-off adhesion test results.

\begin{tabular}{cc}
\hline Coating type & $\begin{array}{c}\text { Adhesive } \\
\text { strength (MPa) } \\
\text { after exposure }\end{array}$ \\
\hline Neat bitumen & 7.8 \\
PNC2 & 8.5 \\
PNC3 & 9.6 \\
PNC4 & 10.2 \\
\hline
\end{tabular}

change in dimension of cut decreases to its minimum amount.

The enhancement of the corrosion resistance of nanocomposite coatings may be due to the nature, shape, and size of the nano-additives, which fill the voids, crevices, and pinholes of the bitumen. As mentioned before, the nanolayers of these additives enforce the corroding agents to travel a tortuous path to reach the substrate, and there is few penetration ways for the corroding agents to diffuse across the section of the scribed regions. Therefore, increasing the layers of nanoclay creates the longer barrier spots toward corroding agents that cause a further increase in corrosion performance of the coating.

\subsection{Pull-off adhesion measurements}

Table 3 represents the pull-off adhesion test results of coatings. Pull-off adhesion data for a coating is an average of at least three times of test. As shown in Table 3, addition of nanoclay improves the wet adhesion of coating to substrate. This is due to the decrease in the penetration of water molecules and aggressive ions by incorporation of nanoclay. Moreover, low amounts of wet adhesion in coating system containing $0 \mathrm{wt} \%$ of clay may be due to the penetration of aggressive ions and molecules into the coating which can lose the adhesion of coating to the substrate and deteriorate other properties of the coating [23]. This effect decreases by increasing nanoclay loading to bitumen matrix.

\section{Conclusion}

A novel nanocomposite material composed of montmorillonite clay and bitumen matrix was successfully developed through solvent intercalation method by mechanical agitation and sonication process. Different loadings of natural montmorillonite clay (Cloisite $\mathrm{Na}^{+}$) were added to bitumen to make 2, 3, and $4 \mathrm{wt} \%$ of clay/bitumen nanocomposite coatings. Polarization and salt fog measurements after exposure periods indicated that bitumen/clay coatings had a greater barrier property than pristine bitumen film. This property enhanced as the nanoparticles loading increased up to $4 \mathrm{wt} \%$. Also, coating adhesion after an extended period of exposure to $\mathrm{NaCl}$ electrolyte increased in 
the presence of MMT clay. This is attributed to the proper dispersion, high intercalation of the loaded clay, and strong interactions between MMT and bitumen matrix (as shown by FT-IR and XRD) which effectively increase the length of the diffusion pathways for oxygen and water.

\section{References}

1. Hamedi Rad, M., Tavakolian, M., Najafi, I., Ghazanfari, M.H., Taghikhani, V. and Amani, M. "Modeling the kinetics of asphaltene flocculation in toluenepentane systems for the case of sonicated crude oils", Scientia Iranica, 20, pp. 611-616 (2013).

2. Singh, B., Kumar, L., Gupta, M. and Chauhan, G.S. "Polymer-modified bitumen of recycled LDPE and maleated bitumen", J. Appl. Polym. Sci., 127, pp. 6778 (2013).

3. Gharazi, S., Ershad-Langroudi, A. and Rahimi, A. "The influence of silica synthesis on the morphology of hydrophilic nanocomposite coating", Scientia Iranica, 18, pp. 785-789 (2011).

4. Ajami, N., Bahrami Panah. N. and Danaee, I. "Oxytetracycline nanosensor based on polyorthoaminophenol/multi-walled carbon nanotubes composite film", Iran. Polym. J., 23, pp. 121-126 (2014).

5. Abbasipour, M. and Khajeh Mehrizi, M. "Investigation of changes of reflective behavior of cotton/polyester fabric by $\mathrm{TiO}_{2}$ and carbon black nanoparticles", Scientia Iranica, 19, pp. 954-957 (2012).

6. Mohamadpour, Sh., Pourabbas, B. and Fabbri, P. "Anti-scratch and adhesion properties of photocurable polymer/clay nanocomposite coatings based on methacrylate monomers", Scientia Iranica, 18, pp. 765-771 (2011).

7. Danaee, I., Darmini, E. and Rashed, G.R. "Selfhealing and anticorrosive properties of $\mathrm{Ce}(\mathrm{III}) / \mathrm{Ce}(\mathrm{IV})$ in nanoclay-epoxy coatings", Iran. Polym. J., 23, pp. 891-898 (2014).

8. Bahrami Panah, N., Payehghadr, M., Danaee, I., Nourkojouri, H. and Sharbatdaran, M. "Investigation of corrosion performance of epoxy coating containing polyaniline Nanoparticles", Iran. Polym. J., 21, pp. 747-754 (2012).

9. Motahari, S., Dornajafi, L. and Fotovat Ahmadi, I. "Migration of organic compounds from PET/clay nanocomposites: influences of clay type, content and dispersion state", Iran. Polym. J., 21, pp. 669-681 (2012).

10. Sun, L., Boo, W.L. and Clearfield, A. "Barrier properties of model epoxy nanocomposites", J. Membr. Sci., 318, pp. 129-136 (2008).

11. Thiagarajan, A., Palaniradja, K. and Mathivanan, N.R. "Effect of nanoclay on the impact properties of glass fiber-reinforced polymer composites", PlymPlast. Technol., 51, pp. 1403-1410 (2012).
12. Bahramian, A.R., Ahmadi, L.S. and Kokabi, M. "Performance evaluation of polymer/clay nanocomposite thermal protection systems based on polyethylene glycol phase change material", Iran. Polym. J., 23, pp. 163-169 (2014).

13. Zhu, H.G., Liu, M.Y., Yuen, R.K.K., Leung, C.K.Y. and Kim, J.K. "Thermal performance and flame retardancy studies of vinyl ester and glass fiber reinforced plastic composites containing Nanoclay", J. Compos. Mater., 48, pp. 165-177 (2014).

14. Darmiani, E., Rashed, G.R., Zaarei, D. and Danaee, I. "Synergistic effects of montmorillonite/cerium nitrate additives on the corrosion performance of epoxy-clay nanocomposite coatings", Polym-Plast. Technol., 52, pp. 980-990 (2013).

15. Gao, F. "Clay/polymer composites: the story", Mater. Today, 7, pp. 50-55 (2004).

16. Zamanizade, H.R., Shishesaz, M.R., Danaee, I. and Zaarei, D. "Investigation of the corrosion protection behavior of natural montmorillonite clay/bitumen nanocomposite coatings", Prog. Org. Coat., 78, pp. 256-260 (2015).

17. Darmiani, E., Danaee, I., Rashed, G.R. and Zaarei, D. "Formulation and study of corrosion prevention behavior of epoxy cerium nitrate-montmorillonite nanocomposite coated carbon steel", J. Coat. Technol. Res., 10, pp. 493-502 (2013).

18. Liu, G., Wu, S., Ven, M.V., Yu, J. and Andre Molenaar, A. "Structure and artificial ageing behavior of organo montmorillonite bitumen nanocomposites", Appl. Clay Sci., 72, pp. 49-54 (2013).

19. Jafari, H., Danaee, I. Eskandari, H. and RashvandAvei, M. "Electrochemical and theoretical studies of adsorption and corrosion inhibition of $\mathrm{N}, \mathrm{N}-\mathrm{Bis}(2-$ hydroxyethoxyacetophenone)-2,2-dimethyl-1,2-propanediimine on low carbon steel (API 5L Grade B) in acidic solution", Ind. Eng. Chem. Res., 52, pp. 6617-6632 (2013).

20. ASTM B-117, Standard Practice for Operating Salt Spray (Fog) Apparatus, Annual Book of ASTM Standards (2011).

21. ASTM D4541-09e1, Standard Test Method for Pull-Off Strength of Coatings Using Portable Adhesion Testers, Annual Book of ASTM Standards (2009).

22. Singh-Beemat, J. and Iroh, J.O. "Characterization of corrosion resistant clay/epoxy ester composite coatings and thin films", Prog. Org. Coat., 74, pp. 173-180 (2012).

23. Turner, R.H. and Boerio, F.J. "Molecular structure of interfaces formed with plasmapolymerized silicalike primer films: Part II. Characterization of the primer/metal interface using x-ray photoelectron spectroscopy in SITU", J. Adhes., 78, pp. 465-493 (2002).

\section{Biographies}

Hamid Reza Zamanizadeh was born in 1989. At present, he is an MSc student of Technical Inspection 
Engineering of Abadan Faculty of Petroleum Engineering in the Petroleum University of Technology.

Iman Danaee was born in 1979 and received his $\mathrm{PhD}$ in electrochemistry in 2009. At present, he is an Assistant Professor of Electrochemistry-Corrosion and teacher and a researcher of Abadan Faculty of Petroleum Engineering in the Petroleum University of Technology.

Mohammad Reza Shishesaz was born in 1954 and received his $\mathrm{PhD}$ in Chemical Engineering in 1988. At present, he is an Associate Professor of Chemical and Polymer Engineering and a teacher of Abadan Faculty of Petroleum Engineering in the Petroleum University of Technology.

Davood Zarei was born in 1972 and received his $\mathrm{PhD}$ in Polymer Engineering in 2009. At present, he is an Assistant Professor of Polymer Engineering and a teacher of Technical Faculty in the South Tehran Branch Islamic Azad University. 